\title{
Sexually transmitted infections, their treatment and urban change in colonial Leopoldville, 1910-1960
}

\author{
João Dinis Sousa ${ }^{1,2}$, Philip J. Havik ${ }^{3 \star}$ and Anne-Mieke Vandamme ${ }^{1,2}$ \\ ${ }^{1}$ Department of Microbiology, Immunology and Transplantation, Rega Institute for Medical Research, Clinical and \\ Epidemiological Virology/Institute for the Future, KU Leuven, Leuven, Belgium \\ ${ }^{2}$ Global Health and Tropical Medicine (GHTM), Unidade de Microbiologia Médica, Instituto de Higiene e Medicina Tropical, \\ Universidade NOVA de Lisboa, Lisbon, Portugal \\ ${ }^{3}$ Global Health and Tropical Medicine (GHTM), Unidade de Clínica Médica, Instituto de Higiene e Medicina Tropical, \\ Universidade NOVA de Lisboa, Lisbon, Portugal \\ ${ }^{*}$ Corresponding author. Email: philip.havik@ihmt.unl.pt
}

\begin{abstract}
During the colonial period sexually transmitted infections (STIs) came to be recognised as a major public health problem in African cities. Thus, STI control and urban modernisation became deeply entangled as authorities redrew spatial and social boundaries to manage populations and their cross-cultural interaction. Public health measures, urban planning and policing were part of a coordinated effort to neutralise the potential impact of rapidly growing African urban migration on the Belgian Congo's 'model' capital Leopoldville. While STI control was facilitated by new drugs (arsenicals, sulfonamides and antibiotics) to treat syphilis, chancroid, gonorrhoea and chlamydia (bacterial STIs), the effects of the 1929 economic crisis and urban social change illustrated the limits of colonial authority. Redesigning urban spaces and repressive measures to curb polygyny and prostitution operated in a parallel fashion with the expansion of health coverage, new treatments and awareness campaigns. To gain a better understanding of the evolution of STI incidence among African urban populations during the colonial period between 1910 and 1960, extensive archival records and secondary literature were consulted to assess the interplay between improved screening, diagnostic and therapeutic methods with demographic and social change. They show that STI rates, probably peaked during the pre-1929 period and apart from a short period in the early 1930s associated with mass screening, declined until becoming residual in the 1950s. Reflecting upon sanitary interventions and their broader dimensions, the article analyses the evolution of treatment regimes and their impact in the changing urban organisation and environment of the colony's capital.
\end{abstract}

Keywords: Sexually transmitted diseases; Colonial health systems; Urbanisation; Social change; Leopoldville; Belgian Congo

\section{Introduction}

Colonial disease control campaigns against infectious and vector borne diseases have been the subject of ample and consistent historical study over the last decades. Successive vertical campaigns against cholera, yellow fever, bubonic plague, leprosy, sleeping sickness, malaria, smallpox, yaws and syphilis turned Africa into a 'living medical laboratory' for scientific development. ${ }^{1}$ Centering upon population management, these campaigns were conducted by colonial regimes guided by the politics of difference, distinguishing between European settlers and the large majority of indigenous African peoples. ${ }^{2}$ With the broader adoption of germ theory and the emergence of tropical medicine, a policy shift in the early

\footnotetext{
${ }^{1}$ Helen Tilley, Africa as a Living Laboratory: Empire, Development and the Problem of Scientific Knowledge, 1870-1950 (Chicago: University of Chicago Press, 2011), 169-216.

${ }^{2}$ Alexandra Widmer and Veronika Lipphardt (eds) Health and Difference: Rendering Human Variation in Colonial Engagements (New York: Berghahn, 2016), 7.

(c) The Author(s), 2021. Published by Cambridge University Press.
} 
1900s shifted attentions to combating successive epidemics by singling out African populations as potential disease reservoirs. ${ }^{3}$ Combining sanitarian with tropical medical notions, colonial policies embraced socio-politically informed urban planning, segregating populations on the basis of racially inspired architectural and hygienic criteria. As a result, cohabitation was supplanted by forms of 'residential sectorisation', creating sanitary cordons by moving African residents to the urban periphery and regulating their access to European zones of settlement. ${ }^{4}$ These measures were further reinforced by curbing local, non-allopathic and cultural practices, including healing and burial traditions, to impose the medicalisation of therapeutic processes within preconceived spatial and social boundaries. ${ }^{5}$ These impositions provoked tensions between authorities and settlers on the one hand and the former and African residents and their representatives on the other, challenging the disruption caused in peoples' daily lives and livelihoods. ${ }^{6}$ One of the most rigorous approaches was experimented in Leopoldville, the capital of the Belgian Congo from the early 1930s onwards, initially as a preventive measure to halt the spread of malaria which had inspired similar interventions elsewhere on the continent. Reacting to the urban migration of Africans, segregation motivated by the 'sanitation syndrome' transformed 'improvised practice into an institutionalised policy'. ${ }^{7}$ However, in practice, informal networks and resistance showed that these boundaries were by no means watertight nor easily enforceable.

In the case of sexually transmitted infections (STI), their rapid spread and the social alarm it provoked among settlers but also among African urban elites, prompted colonial authorities to introduce control measures across colonial Africa, partly based upon similar efforts in Europe. ${ }^{8}$ This meant intervening in the sensitive area of sexual relations through the prism of public hygiene and disease control, setting up clinical facilities and applying biomedical diagnostics and therapeutics to settler and indigenous populations. African sexuality was thus seen as a threat, while Africans were depicted as disease reservoirs which needed to be tackled by urban planning, policing and disease control. It also involved the disciplining of social interactions between European settlers and Africans by means of regulation and surveillance and the targeting of stigmatised groups such as African sex workers and migrant labourer's. ${ }^{9}$ Simultaneously, prostitution emerged as a recurring theme in colonial discourse from the early $1900 \mathrm{~s}$

\footnotetext{
${ }^{3}$ Samuel Coghe, 'Disease control and public health in colonial Africa', in Oxford Research Encyclopedia of African History (New York: Oxford University Press, 2020).

${ }^{4}$ Philip Curtin, 'Medical Knowledge and Urban Planning in Tropical Africa', American Historical Review, 90 (1985), 594-61; Liora Bigon, 'A History of Urban Planning and Infectious Diseases: Colonial Senegal in the Early Twentieth Century', Urban Studies Research (2012), 1-12 and by the same author 'Bubonic Plague, Colonial Ideologies, and Urban Planning Policies: Dakar, Lagos, and Kumasi', Planning Perspectives, 31, 2 (2016), 205-26.

${ }^{5}$ Myron Echenberg, Black Death, White Medicine: Bubonic Plague and the Politics of Public Health in Colonial Senegal, 19141945 (Portsmouth, NH: Heinemann, 2002).

${ }^{6}$ Kalala J. Ngalamulume, 'Keeping the City Totally Clean: Yellow Fever and the Politics of Prevention in Colonial SaintLouis-Du-Senegal, 1850-1914', Journal of African History, 45 (2004): 183-202.

${ }^{7}$ Luce Beeckmans, 'Agency in an African city. The various trajectories through time of the public market in Kinshasa', Karel A. Bakker (ed.) Proceedings of African Perspectives 2009 The African Inner City: [Re]sourced (Pretoria: University of Pretoria, 2009), 115-29.

${ }^{8}$ Kalala J. Ngalamulume, 'Le péril venérien: l'État colonial français et la sexualité à St Louis du Sénégal, 1850-1920', in Jean Paul Bado (ed.) Les Conquêtes da la Médicine Moderne en Afrique (Paris: Karthala, 2006): 99-118; Bryan T. Callahan, Syphilis and Civilization: A Social and Cultural History of Sexually Transmitted Disease in Colonial Zambia and Zimbabwe (Baltimore: John Hopkins University, 2002); Idrissou Alioum, 'Prostitution et lutte contre les maladies vénériennes au Cameroun, 1923-64: discours et pratiques', Kaliao, 2, 4 (2010), 123-41; Philip J. Havik, 'Public Health, Social Medicine and Disease Control: Medical Services, Maternal Care and Sexually Transmitted Diseases in Former Portuguese West Africa (1920-63)', Medical History, 62, 4 (2018), 485-506; Karen Jochelson, The Colour of Disease: Syphilis and Racism in South Africa, 1880-1950 (New York/Oxford: Palgrave/St Anthony's, 2001); Megan Vaughan, 'Syphilis in colonial East and Central Africa, the social construction of an epidemic', in Terence Ranger and Paul Slack (eds), Epidemics and Ideas: Essays on the Historical Perception of Pestilence (Cambridge: Cambridge University Press, 1992), 269-302; Michael W. Tuck, 'Syphilis, Sexuality and Social Control: A History of Venereal Disease in Colonial Uganda' (PhD thesis: NorthWestern University, 1997); Maryinez Lyons, 'Sexually Transmitted Diseases in the History of Uganda', Genitourinary Medicine, 70 (1994), 138-45.

${ }^{9}$ Daniel J. Walter, Sex and Control: Venereal Disease, Colonial Physicians and Indigenous Agency in German Colonialism, 1884-1914 (New York: Berghahn, 2015).
} 
associated with public order, hygiene and sexual mores. As such, its transnational features arose as 'an unanticipated consequence' of modernisation, urbanisation and economic change promoted by colonial states. ${ }^{10}$ The redefining of marital relations in urban areas and women's exclusion from regular employment prompted them to explore novel opportunities to exert their autonomy by generating income in an increasingly monetised economy, of which sex work was just one aspect. ${ }^{11}$

Whereas the literature on STI-related campaigns and their outcomes has largely concerned itself with British and French colonies, former Belgian dominions have benefited from limited medical, social and historical research. ${ }^{12}$ The Belgian Congo has taken on a particular importance in STI-related studies. ${ }^{13}$ The hypothesis that Leopoldville played a crucial role in the emergence and initial spread of HIV-1 associated with high rates of STI transmission, ${ }^{14}$ has underlined the need for focusing on early developments and trajectories of STIs in urban environments in the Belgian Congo. Hence, this article proposes to address under-researched aspects, namely the evolution of STI incidence in Congolese urban environments such as Leopoldville.

The analysis of measures put in place by colonial authorities against 'venereal diseases' in colonial Leopoldville (currently Kinshasa) sets out to trace the burden of STIs in the capital from the 1910s to the late 1950s. To that end, three research questions were formulated. First, whether existing records despite their shortcomings provide a reliable basis for establishing a diachronic perspective upon STI incidence. Secondly, whether they allow for assessing the impact of campaigns and therapeutics in the Belgian Congo and for making comparisons to other colonies during the same period. Third, whether STI trends can be related to political interventions in the capital on the one hand, and to socio-economic changes among African urban populations on the other.

To answer these questions, research was undertaken in Belgian colonial archives, gathering quantitative data from unpublished health reports and policy documents on colonial medicine to determine STI incidence and health coverage in Leopoldville and surrounding areas. Literature on colonial administration and health-related policies was consulted to provide qualitative perspectives on relevant political decision-making affecting the capital's population. Based upon a close reading of these sources, a temporal data series was compiled on STI incidence for the city of Leopoldville for the period in question. The data search comprised records of annual treated case numbers in the city for each pathology or condition between 1885 and 1960, thus covering most of the colonial period. Between 2008 and 2010 and again from 2016 to 2018, research centered on the Afrika-Archief of the Belgian Ministry of Foreign Affairs, which absorbed the archives of the old Ministry of Colonies (Afrika-Archief, Federale Overheidsdienst - Buitenlandse Zaken, Buitenlandse Handel en Ontwikkelingssamenwerking, FO-BZBHO).

Some health reports refer to the urban district that comprised the city (District Urbain de Léopoldville, DUL) for the period 1931-51, including nosological tables of the recorded cases of listed pathologies treated on a yearly basis in the city. Others refer to the entire province which included the city of

\footnotetext{
${ }^{10}$ Saheed Aderinto, 'Journey to Work: Transnational Prostitution in Colonial British West Africa', Journal of the History of Sexuality, 24, 1 (2015), 99-124: 124.

${ }^{11}$ Luise White, The Comforts of Home: Prostitution in Colonial Nairobi (Chicago: University of Chicago Press, 1990).

${ }^{12}$ Nancy Rose Hunt, 'STDs, suffering, and their derivatives in Congo-Zaire: notes towards an historical ethnography of disease', in Charles Becker, Jean-Pierre Dozon, Christine Obbo, et al. (eds), Vivre et penser le sida en Afrique: Experiencing and Understanding AIDS in Africa (Paris: Karthala, 1999), 111-31; J. Goeman, A. Meheus and P. Piot, 'Sexually transmitted diseases', in P.G. Janssens, M. Kivits and J. Vuylsteke (eds), Health in Central Africa Since 1885: Past, Present, and Future (Brussels: King Baudoin Foundation, 1997), 635-52.

${ }^{13}$ A. Dubois and A. Duren, 'Soixante ans d'organisation médicale au Congo belge', Annales de la Société Belge de Médecine Tropicale, 27, Supplement. Lib. Jub. J. Rodhain (1947), 1-36; Goeman et al., ibid.; Hunt, ibid.; Janssens et al., ibid.; Jacques Pépin, The Origins of AIDS (Cambridge: Cambridge University Press, 2011).

${ }^{14}$ João Dinis Sousa, Viktor Müller, Philippe Lemey, Anne-Mieke Vandamme, 'High GUD Incidence in the Early $20^{\text {th }}$ Century Created a Particularly Permissive Time Window for the Origin and Initial Spread of Epidemic HIV Strains', PLoS ONE, 5, 4 (2010), e9936, URL: http://www.plosone.org/article/info:doi/10.1371/journal.pone.0009936.
} 
Leopoldville (the Congo-Kasai province up to 1932 and the Leopoldville province from 1933 onwards). ${ }^{15}$ Colony-level reports present nosological tables by provinces and districts, which facilitated the extraction of DUL-level data, including cases referring to African patients, 'hospitalised' and 'hospitalised or not'. The latter have been consistently used here. If only the former were available, data for that year were marked as non-existent. ${ }^{16}$ As a result of unreliable data for the period 1910-18, they were excluded, so that the data series commences in 1919. STI data were also extracted from the reports by the Croix Rouge $d u$ Congo which ran important clinics in Leopoldville specialised in venereal diseases. ${ }^{17}$ Demographic data for the city were taken either from the health reports themselves or from the colonial reports of the inventory Affaires Indigènes et Main d'Oeuvre consulted also at the Afrika-Archief. ${ }^{18}$ In order to compare the situation in the Belgian Congo with other colonies, we consulted French colonial archives in Aix-enProvence (Archives Nationales d'Outre-Mer, ANOM) and Marseille (Institut de Médecine Tropicale du Service de Santé des Armées, IMTSSA), as well as Belgian and French publications on colonial medicine.

Finally, an extensive review of published sources was conducted in libraries and on-line on urbanisation, territorial (re)organisation and its impact upon African populations in Leopoldville. Hence, the city's changing demography, social and economic developments and securitarian policies are related to STI-targeted health campaigns and their impact upon urban strata.

\section{The health system and the production of biostatistics}

In the Belgian Congo, healthcare was provided by different sectors (or systems): government run hospitals and dispensaries; the so-called 'Organisations Philantropiques' (Croix Rouge du Congo; Fonds Reine Elisabeth pour l'Assistance Médicale aux Indigènes, FOREAMI, Fondation Médicale de l'Université de Louvain au Congo, FOMULAC); itinerant services (mobile teams, operating in rural areas); religious missions; rural dispensaries run by the Assistance Médicale Indigéne Bénévole, AMIB); and private enterprises ('Hygiène Industrielle'). From the inception of the colony's Service d'Hygiène Publique (Public Health Service) in 1922, Leopoldville's health system was operated by a public, government-based sector, as well as the Croix Rouge du Congo à Léopoldville (CRC; considered a philanthropic organisation, erected in 1926) and services run by private enterprises. Government sourced health reports include health statistics with the cases treated by government led services (GOV), while most Hygiène Publique reports have a section on Hygiène Industrielle (HI), providing data on cases and patients treated by private enterprises. The cases treated in CRC were recorded Croix Rouge reports and often also reproduced in separate sections of other reports. ${ }^{19}$ This allowed for the creation of a non-overlapping dataset: none of the cases of a disease reported for the DUL was referred in multiple sections or tables; if reported in the main table, it was a GOV case. If it was treated as a CRC case in the Croix Rouge reports, without overlap with GOV cases, since the Croix Rouge was a philanthropic organisation. If reported in the HI table, it was neither GOV or CRC. The two hospitals, twelve health dispensaries/clinics and several other health facilities treating Africans in the city by 1937 all belonged to one of the three

\footnotetext{
${ }^{15}$ Afrika-Archief (FO-BZBHO, Brussels), A39-81, -82, -87, -88, -89, and RACBGG-513, 514, 'Province du Congo-Kasai, Rapport du Service Médical pendant l’année [1919-32]', Leopoldville, Belgian Congo: Service de l'Hygiène Publique, 1919-32; Afrika-Archief (FO-BZBHO, Brussels), A39-135, -136, -252, -253, -254, A39-RA-RA/MED-16, -17, -18, and RACBGG-513, -514, 'Province de Léopoldville, Rapport du Service Médical pendant l'année [1933-58]', Leopoldville, Belgian Congo: Service Médical, 1933-58.

${ }^{16}$ For the years 1910-12, 1915-16 and 1918, the health reports stored in the Afrika-Archief only contain DUL-level data referring to hospitalised African patients. For the years 1913-14 and 1917 no DUL-level data referring to Africans have been found.

${ }^{17}$ Afrika-Archief (FO-BZBHO, Brussels), A39-RA-RA/MED-6 and GG-5398, Croix Rouge du Congo, Croix Rouge du Congo, Rapport annuel [1928-54] (Brussels: Croix Rouge de Belgique, 1928-54).

${ }^{18}$ Afrika-Archief (FO-BZBHO, Brussels), A39-RA-RA/AIMO-119, -119-annexe, -120, -120-annexe, -236, -237. 'Affaires Indigènes et Main d'œuvre, District Urbain the Léopoldville, Rapport Annuel [1926-52]', Leopoldville, Belgian Congo: AIMO, 1926-52.

${ }^{19}$ Croix Rouge du Congo, op. cit. (note 17).
} 
categories mentioned above. ${ }^{20}$ Therefore, for each disease, the sum GOV + CRC $+\mathrm{HI}$, reliably provides the number of treated and recorded cases in DUL.

Colonial reports tend to divide the city of Leopoldville (or 'Leo', as it was often designated) in two areas, Leo-West and Leo-East, the latter the more industrialised and more populous part, already by 1920. The designation 'Leo-East' was used interchangeably with 'Kinshasa', named after an important pre-colonial village. After independence, the Congolese authorities used the name 'Kinshasa' to refer to the combined area. In this study, we focus on the whole of Leopoldville (West and East). Following the creation of specialised agencies and departments during the interwar years which centered on hospitals and mobile services - based upon the Jamot model in French colonies - for case finding and monitoring a variety of endemic diseases, above all sleeping sickness, after 1945 an attempt was made to integrate them in the Belgian Congo's fragmented health system. The Van Hoof-Duren Plan which was included in the Plan Décennal (or Ten-Year Plan) divided the colony in medical (sub-)sectors, including the capital, reserving $14.6 \%$ of the budget to equipping it with medical surgical centres linked to networks of satellite dispensaries. $^{21}$ These reforms shifted the emphasis of the health system to fixed horizontal services, which expanded considerably, facilitating data collection. As a result, health data bases, albeit fragmented, greatly expanded during the 1950s. Nevertheless, biostatistics should be treated with caution. ${ }^{22}$

The debate on the use of colonial statistics has raised the issue of their reliability and bias, their varying quality, the existence of diachronic gaps and the absence of certain data. Discussions have above all looked at the production and quality of demographic and economic data during the colonial period, with little attention being paid to biostatistics. ${ }^{23}$ So far, no detailed assessment of the quality of the latter for the Belgian Congo has been carried out. Hence, the present study has taken considerable care to assess the reliability of STI-related data whenever possible. Given the fact that the bulk of STI-related data was produced by the Croix Rouge, only part of the data set was directly state-sourced.

In terms of case numbers for different diseases figuring in health reports of African colonies, these cannot, in general, be reliably used to calculate incidence rates at the population level, because many or most disease cases were neither treated or diagnosed and the demographics of entire regions were not well known. In the Belgian Congo as elsewhere, treated cases increased as the health system expanded. Accordingly, after gathering data from the Belgian Afrika-Archief, from French archives (ANOM, IMTSSA), and additional sources (listed in Appendix), treated patient numbers at the colonial, provincial and regional levels grew steadily throughout the colonial period (Figure 1). This reflects increasing health coverage of the population and growing diversity of both the health conditions treated and the treatments and interventions performed, rather than the increase of disease epidemics.

However, for the city of Leopoldville, the situation was rather different. As the colony's capital, it boasted two hospitals and many clinics for Africans, and far more MDs per capita than the colony itself. Record keeping of diseases gained efficacy from 1919 onwards. By the mid-1920s, owing to demographic, economic and political concerns, a deliberate policy was implemented to treat all cases of venereal diseases. ${ }^{24}$ Thus, the increase in STI data forms part of a broader attempt to exercise greater control over the African population, and labourers in particular. Records were kept for each worker, showing his or her history of treatments for different diseases such as trypanosomiasis, syphilis, other diseases and vaccinations. Immigration into the city was regulated by means of a pass system, checkpoints and policing. Africans were hired in groups by special agents working either for the government or for enterprises, often against their will. This facilitated

\footnotetext{
${ }^{20}$ AIMO, op. cit. (note 18), 1937 report.

${ }^{21}$ Guy Vanthemsche, Genèse et portée du Plan Décennal du Congo Belge, Mémoire, Académie Royale des Sciences d'Outre Mer, 51, 4 (1994).

${ }^{22}$ Maryinez Lyons, 'Public health in the Belgian Congo', in Dorothy Porter (ed.) The History of Public Health and the Modern State (Amsterdam: Rodopi, 2006), 356-84, 373; Pépin, op cit. (note 13), 146.

${ }^{23}$ Morten Jerven, Poor Numbers: How We Are Misled by African Development Statistics and What to Do About It (Ithaca: Cornell University Press, 2013); Jean Paul Sanderson, Démographie coloniale congolaise: entre speculation, idéologie et reconstruction historique (Louvain: PU Louvain, 2019); Pépin, op cit. (note 13), 148.

${ }^{24} \mathrm{P}$. Walravens, 'Prophylaxie des Maladies Vénériennes', Revista Médica de Angola, 2, 4, special issue, First West African Congress on Tropical Medicine (1923), 157-65.
} 


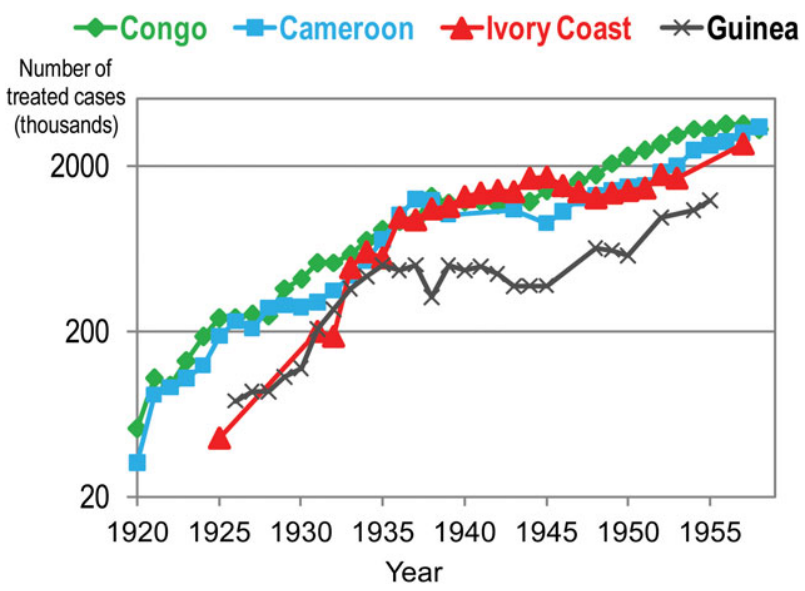

Figure 1. The annual number of treated people for any condition in Belgian Congo, Cameroon, Ivory Coast and Guinea. The sources are listed in Appendix.

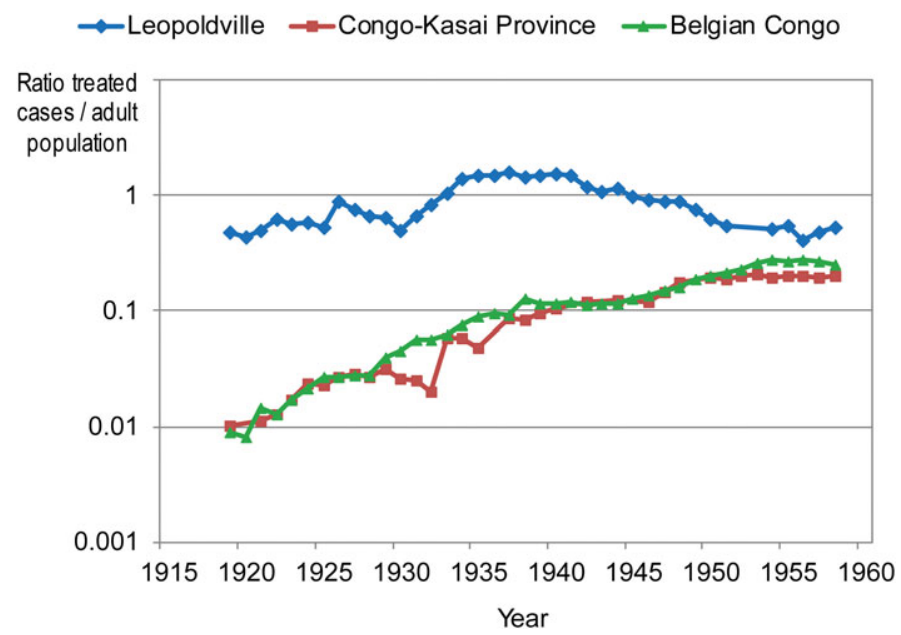

Figure 2. The ratio between annual number of treated people (government health sector) and population, for the city of Leopoldville, for the province of Congo-Kasai/Leopoldville and for the colony as a whole.

Sources: Province du Congo-Kasai, op. cit. (note 3); Province de Léopoldville, op. cit. (note 3); RAACCB, op. cit. (note 4); RHPCB 1908-24, op. cit. (note 4); RHPCB 1925-58, op. cit. (note 4); AIMO, op. cit. (note 7); Duren, op. cit. (note 9); District Urbain de Léopoldville, op. cit. (note 9).

census taking in the DUL, specifying population numbers and their breaking down by gender, age, quarter within the city and even district of origin. ${ }^{25}$ As a result, high levels of screening and treatment, particularly for STIs, were a common feature for the period 1920-60.

This trend can be confirmed when observing the ratio between treated cases and the entire population, a proxy for health coverage. To measure the latter, we took the annual number of treated disease cases (any condition), considering only patients of the hospitals or clinics sponsored by the government (but not including the work of mobile teams), separately for the city of Leopoldville, for the Congo-Kasai province (Leopoldville province from 1933 onwards) - and for the colony as a whole - for the period 1919-58 (Figure 2).

\footnotetext{
${ }^{25}$ Province de Léopoldville, op. cit. (note 15); AIMO, op. cit. (note 18); District Urbain de Léopoldville, op. cit. (note 18).
} 
As Figure 2 shows, for the colony and the province, both of which comprised mostly rural populations, the ratio was about $1 \%$ in 1919, increasing more than twenty-fold until the late 1950s. This illustrates that government health clinics and hospitals were serving few rural Congolese in the early decades of colonialism (although rural areas were served by mobile teams, treating trypanosomiasis, yaws and other tropical diseases, since the 1920s). The increase in treated cases thus mainly reflects extended health coverage, but also the growing diversity of diseases, available treatments and available serological and other diagnostic techniques. But in the capital city, the ratio was already high in the early 1920s, fluctuating only moderately during the four decades under study (Figure 2), showing a consistent high level of use of hospitals and clinics by the urban population. The moderate decline of the ratio after the 1940s reflects, at least in part, the increasing efficacy of treatments, and their less cumbersome nature, which tended to provide better outcomes for patients and reduced the frequency of visits to health facilities.

Therefore, the evolution of the ratio (patients treated for a particular disease)/(population) at colonial or provincial level cannot be taken as an evolution of the incidence for that disease. However, given the consistently high health coverage for Leopoldville (Figure 2), the evolution of this ratio will tend to reflect the evolution of incidence in this city. Focusing on STIs, an important caveat needs to be made here, that in current day sub-Saharan Africa, about half of individuals experiencing STI symptoms do not seek healthcare. ${ }^{26}$ In all likelihood, this form of selective institutional health seeking behaviour also occurred in colonial Leopoldville. Thus, if it is assumed that this effect was more or less constant over the period in question, temporal variations in the ratio of number of treated patients versus population size essentially reflect changes in health coverage. Since these changes were moderate in Leopoldville, as Figure 2 shows, the evolution of the ratio of newly treated cases for a particular STI versus the adult population should reflect the evolution of incidence for this STI. This ratio is referred here as the annual incidence of treated cases, a common expression in epidemiology. ${ }^{27}$ Even though the incidence of the disease itself is likely to be higher, the temporal evolution of both incidences will be similar.

At the clinical level, the accuracy of STI diagnoses in the early 1900s was by no means optimal because STI symptoms overlap to a large extent. ${ }^{28}$ In addition, the available serological tests were unreliable and identification of bacterial STIs by cell culture was rarely undertaken. The serological test to diagnose syphilis (caused by Treponema pallidum pallidum) most used in colonial times was the BordetWassermann test, which has a low specificity, being reactive for other treponematoses such as yaws (Treponema pallidum pertenue), for malaria, tuberculosis, leprosy and other conditions. ${ }^{29}$ In Leopoldville and for most of the period under study, most diagnoses were clinical, or a combination of clinical and serological. Only by the 1950s, a high proportion of syphilis diagnoses were made in the latent stage (detected by serology), as cases of early infectious syphilis became rare. ${ }^{30}$ In early twentieth century Leopoldville, most cases were detected in the primary or secondary stages. These would have had a limited overlap with yaws given that it does not cause a primary chancre like syphilis, seldom affects mucosa and symptomatic early yaws is seen overwhelmingly in children, while early syphilis is a disease affecting adults. ${ }^{31}$ Therefore, mistaking yaws for syphilis probably occurred mostly in tertiary and latent

\footnotetext{
${ }^{26}$ The DHS Program, Demographic and Health Surveys (Calverton, Maryland: ICF International), URL: http://dhsprogram. com.

${ }^{27}$ See, Michael Goldacre, Raj Shiwach, David Yeates, 'Estimating Incidence and Prevalence of Treated Psychiatric Disorders from Routine Statistics: The Example of Schizophrenia in Oxfordshire', Journal of Epidemiology and Community Health, 48 (1994), 318-22.

${ }^{28}$ King K. Holmes, Per-Anders Mårdh, P. Frederick Sparling, et al. (eds), Sexually Transmitted Diseases, 2nd edition (New York: McGraw-Hill, 1984).

${ }^{29}$ Krystin Fagerberg, 'Wassermann test', in Jill Grimes (ed.), Krystin Fagerberg and Lori Smith (co-eds), Sexually Transmitted Diseases: An Encyclopedia of Diseases, Prevention, Treatment, and Issues (Santa Barbara: ABC-CLIO Greenwood, 2014), 724-5.

${ }^{30}$ Province de Léopoldville, op. cit. (note 3); P. Bruaux, J. Cerf, A. Lebrun, 'La lutte contre les affections vénériennes à Léopoldville’, Annales de la Société Belge de Médecine Tropicale, 37, 6 (1957), 801-13: 807.

${ }^{31}$ Cartron, 'Le Pian et sa Répartition dans les Colonies Françaises', Annales de Médecine et de Pharmacie Coloniales, 35 (1937), 5-73; C.J. Hackett, 'Extent and Nature of the Yaws Problem in Africa', Bulletin of the World Health Organization, 8 (1953), 129-82.
} 
cases. Such mistakes may have affected our data on syphilis for the period 1940-60, when tertiary and serological cases predominated.

Some non-syphilitic genital ulcers (e.g. chancroid's chancres) may have been confounded with syphilis. However, most syphilis chancres are indurated and painless and thus distinguishable from chancroid's soft and painful chancres. ${ }^{32}$ In addition, chancroid was often identified once the lesions did not regress after specific anti-syphilis arsenical or other treatment. ${ }^{33}$ Despite clinical experience some chancroid cases may have been misdiagnosed as syphilis. ${ }^{34}$

Urethral and cervical discharge is mostly caused by Neisseria gonorrhoea, Chlamydia trachomatis or, in women, Trichonomas vaginalis, but the causative role of the latter two pathogens was not known for most of the period under study. The reports only mention the condition of 'blennorrhagie', which nowadays refers only to gonorrhoea. No sensitive and specific laboratory diagnostic tests existed for these pathogens and attempts to detect them by cell culture were not made. Therefore, cases cannot be broken down by causative pathogen, and thus the reported number of cases of discharge ('blennorrhagie') syndrome is presented here.

Lymphogranuloma venereum (LGV), also called lymphogranuloma inguinale, or Nicolas-Favre disease is a complex STI caused by specific strains of Chlamydia trachomatis. A typical manifestation is an inguinal bubo ('bubon vénérien' in the colonial reports) seen overwhelmingly in men. It causes rectal strictures (genito-ano-rectal syndrome, GARS) and long-lasting genital lesions ('esthiomène' or 'syphilomes' in the colonial reports), mostly in women. By the late 1920s it was established that these different conditions were caused by the same agent. ${ }^{35}$ Leopoldville colonial reports record cases of bubon vénérien (mostly found in males) up to the mid-1930s, thereafter being reported as 'lymphogranulomatose' or 'Nicholas-Favre disease' (encompassing both the venereal bubo and the other forms). GARS and esthiomène in women were commonly observed in Leopoldville, but this information originates from isolated surveys, and the annual number of cases was not recorded. ${ }^{36}$

\section{Urban development, demography and social change}

In 1923, the capital of the Belgian Congo was transferred from Boma to Leopoldville, introducing new forms of urban planning and services to a city with an already growing economic importance. Following the introduction of urban planning in 1918, the city's resident population amounted to about 21 000-23 000 in 1922, the overwhelming majority African. Thereafter, it increased rapidly, reaching a peak of 47 500 in 1929, coinciding with the economic and infrastructure development boom. ${ }^{37}$ Following the 1929 international economic crisis which shattered 'the illusion of economic prosperity' following the

\footnotetext{
${ }^{32}$ A.R. Ronald and W.L. Albritton, 'Chancroid and Haemophylus ducreyi', in King K. Holmes, Per-Anders Mårdh, P. Frederick Sparling, et al. (eds) Sexually Transmitted Diseases (New York: McGraw-Hill, 1984), 385-92: 385; Richard P. DiCarlo and David H. Martin, 'The Clinical Diagnosis of Genital Ulcer Disease in Men', Clinical Infectious Diseases, 25 (1997), 292-8: 292.

${ }^{33}$ E. Rebuffat, 'Contribution à l'étude de relèvement de la natalité au Congo Belge' (unpublished manuscript, Library of the Institut voor Tropicale Geeneskunde, Antwerpen, Belgium, 1927), URL: http://libra.itg.be:8000/webspirs/start.ws.

${ }^{34}$ Y. Dangor, R.C. Ballard, F.L. Exposto, et al., 'Accuracy of Clinical Diagnosis of Genital Ulcer Disease', Sexually Transmitted Diseases, 17, 4 (1990), 184-9, URL: https://journals.lww.com/stdjournal/Citation/1990/10000/Accuracy_of_Clinical_ Diagnosis_of_Genital_Ulcer.7.aspx.

${ }^{35}$ H.N. Cole, 'Lymphogranuloma inguinale, the fourth venereal disease', Journal of the American Medical Association, 101, 14 (1933), 1069-76: 1072; M. Favre and S. Hellerström, 'The Epidemiology, Aetiology, and Prophylaxis of Lymphogranuloma Inguinale', Acta Dermato-Venereologica, 34, Suppl 30 (1954), 1-69: 4-5.

${ }^{36}$ District Urbain de Léopoldville, op. cit. (note 9). Since venereal bubo was the only LGV condition systematically reported, case numbers were used whenever reference was made to 'bubon vénérien' and to estimate the proportions of LGV that were venereal bubo whenever 'lymphogranulomatose' or 'Nicholas-Favre disease' were mentioned.

${ }^{37}$ Sylvie Ayimpam, Vie matérielle, exchanges et capitalisme sur la rive méridionalle du Pool du fleuve Congo (1815-1930) (Aix-en-Provence: Centre d'Étude des Mondes Africains MMSH, Collection 'Clio en @frique', 18, 2006), 24; Afrika-Archief (FO-BZBHO, Brussels), A39-RA-RA/MED-46 and RACBGG-553, Letter from the Commissaire de la Province de Léopoldville to the Gouverneur Général, 12 February 1935.
} 
intensive extraction of human and material resources, ${ }^{38}$ the population strongly declined to 22000 by 1933. The severe impact upon mining and agriculture and the colony's exports caused Belgian settlers to return home whilst African labourers sought employment elsewhere, for example, in the neighbouring Rhodesian copper belt. Subsequent tax increases on African populations provoked disorders in the Kwango district and elsewhere, hardening administrative controls and surveillance and leading to the division of the colony in economic zones. Divided between the commercial hub of Kinshasa and the administrative centre in Leo-West, the two sections of the city developed in a parallel fashion, whilst a policy of racially inspired segregation sought to minimise interaction between a largely European elite and rapidly growing 'quartiers Africains'. A male African workforce, the so-called 'boys' who served settler households, formed the only local contingent permitted to cross spatial boundaries. ${ }^{39}$ Subsequently, the capital experienced a significant demographic growth to 43600 in 1939, of which about 40 000 were African, and to 110300 in 1946, totalling 342000 in 1958 while comprising 300000 Africans, on the eve of independence. ${ }^{40}$

By the late 1920s, the already existing Cités such as Leo-East (Kinshasa) and Leo-West (currently the Kintambo quarter) were regarded as problematic in terms of sanitary conditions owing to the threat of possible epidemics, including yellow fever, bubonic plague and meningitis. ${ }^{41}$ Medical services, the Services d'Hygiène, were established in the city in 1922, and in the colony as a whole, which included teams paying regular visits to indigenous neighbourhoods such as Kinshasa. Campaigns were initiated to improve the city's sanitation and hygiene, while sanitary brigades combated endemic diseases such as malaria and yellow fever. At the same time, large enterprises were obliged to create better living conditions for their workers who were housed in camps on the city's outskirts. ${ }^{42}$ During the 1920s, major infrastructural interventions were implemented in Leopoldville, including an improvement of the railway network connecting it to the Belgian Congo's Atlantic port in Matadi, inaugurated in 1898, and of the fluvial ports and industries established along the Congo River basin. To that end, thousands of men were brought in from remote areas of the colony. This caused the city's population to increase two and half fold between 1919 and 1929. The city's shifting demographic had a notable impact on the population's composition, owing to an influx of uprooted, 'detribalised' Africans and a significant gender imbalance, as a 'dangerously large number of bachelor men' were migrating to the cities. ${ }^{43}$ These changes were regarded by authorities as a social, security and health hazard, prompting them to intensify social and medical surveillance. ${ }^{44}$

Significant migratory movements, involving above all young African males, induced by these projects, prompted the Croix Rouge du Congo to establish the first 'dispensaires des maladies vénériennes' (venereal disease dispensaries) in Leopoldville in 1929 and in Matadi in 1938. During the next decade, Croix Rouge reports suggest that the combat against STIs among African populations appeared to centre

\footnotetext{
${ }^{38}$ Bogumil Jewsiewicki, 'The Great Depression and the Making of the Colonial Economic System in the Belgian Congo', African Economic History, 4 (1977), 153-76: 155.

${ }^{39}$ Valérie Piette, 'La Belgique au Congo ou la volonté d'imposer sa ville? L'exemple de Léopoldville', Révue Belge de Philologie et d'Histoire, 89, 2 (2011), 605-18.

${ }^{40}$ Province du Congo-Kasai, op. cit. (note 3); Province de Léopoldville, op. cit. (note 3); AIMO, op. cit. (note 6); Afrika-Archief (FO-BZBHO, Brussels), A39-RA- RA/MED-46 and RACBGG-553, 'District Urbain de Léopoldville, Rapport sur l'Hygiène Publique pendant l'année [1931-51]', Leopoldville, Belgian Congo: Service de l'Hygiène Publique, 1931-51; A. Duren, 'Quelques données sur la situation démographique de la cité indigène de Léopoldville entre 1923 et 1947’, Bulletin des Séances, Institut Royal Colonial Belge, 21, 3 (1950), 708-17; Piette, op cit. (note 39), 611.

${ }^{41}$ Michel Lusamba Kibayu, La typologie des quartiers dans l'histoire du développement de Léopoldville-Kinshasa en République Démocratique du Congo, Territoires et Développements Durables, Notes de Recherche 2008-1 (Louvain-la-Neuve, Belgium: Institut d'études du développement, 2008), 33.

${ }^{42}$ Piette, op cit. (note 39), 615.

${ }^{43}$ Nancy Rose Hunt, 'Noise Over Camouflaged Polygamy, Colonial Morality Taxation, and a Woman-Naming Crisis in Belgian Africa', The Journal of African History, 32, 3 (1991), 471-94: 479.

${ }^{44}$ Amandine Lauro, 'Suspect cities and remaking of colonial order: urbanization, security anxieties and police reforms in Post-War Congo (1945-1960)', in: Jonas Campion and Xavier Rousseaux (eds) Policing New Risks in Modern European History (Palgrave McMillan, 2016), 57-85.
} 
upon areas most associated with infection among European settlers in Leopoldville. ${ }^{45}$ The adult male/ female ratio fluctuated between three to one, and four to one throughout that decade. The authorities considered that this ratio favoured the spread of prostitution. ${ }^{46}$ As the erosion of the widespread practice of polygyny was thought to drive women into urban areas and engage in prostitution, authorities exercised close control over 'femmes libres' or 'femmes seules' access to cities while resident 'women theoretically living alone' were, from 1929 onwards, subject to a special tax. ${ }^{47}$ The justification given was that the vast majority of single African women would be engaging in 'prostitution'. ${ }^{48}$ As the number of single women increased in the 'centres extra-coutumiers' of colonial towns and cities, the revenue from this tax grew considerably. ${ }^{49}$ According to official reports, of 6000 women living in Leopoldville-East in 1928, only 1724 were married (and not 358, as stated elsewhere ${ }^{50}$ ), 1600 had 'illegitimate relationships of varying duration' and the remaining 2676 (45\% of the female population) were presumed to 'live mainly on prostitution'. ${ }^{51}$ The authorities called them interchangeably 'femmes libres' or 'prostitutes', reflecting the exaggerations, prejudices and name-calling typical of colonial societies. ${ }^{52}$ Colonial discourse thus deepened a gendered dichotomy in which French idiom favoured male status, whereas local ethnic vernacular was used pejoratively for women. ${ }^{53}$

The presence of African women in Kinshasa and Leopoldville was not only associated with the expansion of municipal markets in the city from the 1930s onwards, but also with burgeoning informal markets owing to increased urban migration after $1945 .^{54}$ The fact that dowries were increasingly paid in cash and at rising rates, illustrated the growing monetisation of social custom and markets whilst pressures on households increased to augment family income. The adoption of local ethnic idiom such as ndumba, meaning young girl in Kikongo, as a term for 'young courtesan' in an urban setting, preferring single status and a remunerative career associated with nightlife venues of the capital, is revealing for the shifting gender relations during the colonial period. ${ }^{55}$ It also illustrated that the influx of women contributed to changing urban life styles, gains in mobility and transgressive behaviour reproduced in popular culture. ${ }^{56}$ The move away from the traditional polygynous marriage patterns in a rural ethnic context to more fluid forms of intercultural relatedness in towns and cities, a common phenomenon in colonial Africa at the time, provided young women with a range of different options. The 'modern' city affected social relations in a broader sense, aggravated by economic hardship during the crisis years, resulting in forms of gendered, intra-household bargaining marked by a strong gender imbalance. They signal that many young women

\footnotetext{
${ }^{45}$ Hunt, op. cit. (note 12), 114.

${ }^{46}$ Province du Congo-Kasai, op. cit. (note 3); AIMO, op. cit. (note 7).

${ }^{47}$ Hunt, op. cit. (note 43): 479, 483, 489; Ch. Didier Gondola, Villes Mirroirs: migrations et identités urbaines à Kinshasa et Brazzaville 1930-1970 (Paris: Harmattan, 1997), 108.

${ }^{48} \mathrm{Ch}$. Didier Gondola, 'Unies pour le meilleur et pour le pire: femmes africaines et villes coloniales: une histoire du métissage', Clio, 6 (1997): 87-104.

${ }^{49}$ Amandine Lauro, Coloniaux, Ménagères et Prostituées au Congo Belge (1885-1930) (Loverval, Belgium: Éditions Labor, 2005): 171-2.

${ }^{50}$ Tamara Giles-Vernick, Ch. Didier Gondola, Guillaume Lachenal, William H. Schneider, 'Social History, Biology, and the Emergence of HIV in Colonial Africa', The Journal of African History, 54, 1 (2013), 11-30: 22, URL: https://www.cambrid ge.org/core/journals/journal-of-african-history/article/social-history-biology-and-the-emergence-of-hiv-in-colonial-afri ca/391E7322C9065F79D6B4C7B7DEBDA0B2.

${ }^{51}$ Afrika-Archief (FO-BZBHO, Brussels), A39-RA-RA/AIMO-119, Wauters, Commissaire du DUL, 'Rapport sur le récensement de la population indigène', Leopoldville, March 14, 1929.

${ }^{52} \mathrm{Hunt}$, op. cit. (note 43). Also see, Amandine Lauro, 'Une œuvre d'étaiement et de reconstruction'. Notes sur la fabrique du droit coutumier, le pouvoir colonial et l'ordre du mariage dans le Congo belge de l'entre-deux-guerres', in: Charlotte Braillon, Laurence Montel, Bérangère Piret and Pierre-Luc-Plasman (eds), Droit et Justice en Afrique colonial: traditions, productions et réformes (Brussels: Université de St. Louis, 2014): 165-88.

${ }^{53}$ Gondola, op cit. (note 48 ), 4/5.

${ }^{54}$ Luce Beekmans and Liora Bigon, 'The Making of the Central Markets of Dakar and Kinshasa: From Colonial Origins to the Post-Colonial Period', Urban History, 43, 3 (2014), 412-34.

${ }^{55}$ Gondola, op.cit. (note 48), 254; Hunt, op. cit. (note 12), 120/1. Legislation introduced in the capital in 1932 allowed 'persons of colour' to sell alcoholic beverages, while only in 1955 non-evolués were allowed to sell and consume them.

${ }^{56}$ Gondola, op cit. (note 48), 254/255.
} 
chose not to conform to a colonial nuclear family ideal and fulfil a domesticised motherhood role, carving out livelihoods of their own while exploring polyandrous and informal solidarity networks. ${ }^{57}$

Colonial campaigns against polygyny which were introduced in Leopoldville in 1930 were a reaction to the perceived perpetuation of African customs owing to large scale labour recruitments, road and railway construction, industrialisation and trade. In conjunction with religious missions, authorities also attempted to convince the evolués - Africans living in an urban environment who benefited from a formal education and held remunerated employment - to collaborate in their 'civilising mission' by setting an example. Their calls for promoting monogamous marriages and combat prostitution were echoed in the local press: 'Evolués, be dynamic, let us fight this plague of prostitution which is devastating our dear Congo!'. ${ }^{8}$

Rather than being sex workers, most femmes libres would have had several male partners, often sharing a household with them. ${ }^{59}$ Not only 'femmes libres' were the target of policies but also married women engaging in part-time relationships. ${ }^{60}$ Court proceedings show how evolué husbands used penal sanctions to demand compensation for their wives' alleged infidelities. The application of monetary indemnities rather than corporal punishment was seen by some officials to encourage prostitution. ${ }^{61}$ Some authors have stated that 'Kinshasa's pre-Second World War "prostitution" entailed an array of sexual, affective, and domestic services that were offered to a few regular African and European customers in exchange for money, shelter, and food'. ${ }^{62}$ They cast doubt upon the idea that Kinshasa's prostitutes would have had a turnover of several hundreds of clients per year, as stated in a publication by Sousa and colleagues. ${ }^{63}$ Such a high turnover would have been typical for 'commercial sex workers' who maintained brief, anonymous sexual encounters with clients. However, the above publication explicitly stated that this applied to a very small - albeit unquantifiable - minority of the city's female population. ${ }^{64}$ For the overwhelming majority of unmarried women, they would have had a small number of different partners per year, in line with the findings of other authors. ${ }^{65}$

The Commission pour la Protection des Indigènes already signalled the increasing unease in the 1930s over confounding single women with prostitutes, defending the 'modesty and honesty' of widows and divorced and abandoned women. ${ }^{66}$ One of the key factors inciting a shift in social behaviour was the 1929 economic crisis during which African households had to bear the brunt of tax increases, and the loss of employment and income, as economic and social controls were enforced in the capital severely limiting their physical and social mobility. In addition, increased surveillance with the collaboration of native chiefs in urban 'extra-coutumier' areas enabled authorities to expel unwanted individuals from the capital by administrative means. ${ }^{67}$ The question of STI control thus intersects with these securitarian concerns which targeted African quarters, and the overlapping of politico-economic and health surveillance from the 1930s onwards.

A few authors have suggested that there were no prostitutes with a high turnover of 'anonymous and brief encounters in Leopoldville in the 1920s and 1930s, ${ }^{68}$ whereas others refute that brothels existed as

\footnotetext{
${ }^{57}$ Ibid., 5.

${ }^{58}$ Jérome Ernest Mupenda, 'Prostitution et polygamie', La Voix du Congolais 3, 19 (1947), 821-2; also see Étienne Ngandu, 'La prostitution ronge le Congo', La Voix du Congolais, 6 (1945), 209-10.

${ }^{59}$ Lauro, op. cit. (note 49), 88-97.

${ }^{60}$ Pépin, op. cit. (note 13), 94; Bruaux et al., op. cit. (note 30); Suzanne Comhaire-Sylvain, Femmes de Kinshasa hier et aujourd'hui (Paris: Mouton, 1968), 29; Amandine Lauro, “J'ai l'honneur de porter plainte contre ma femme”: Litiges conjugaux et administration coloniale au Congo belge (1930-1960)', Clio. Femmes, Genre, Histoire, 33 (2011).

${ }^{61}$ Lauro, op cit. (note 52), 185.

${ }^{62}$ Giles-Vernick et al., op. cit. (note 50 ).

${ }^{63}$ Sousa et al., op cit. (note 14).

${ }^{64}$ Ibid., 13.

${ }^{65}$ Lauro, op. cit. (note 49); Giles-Vernick et al., op. cit. (note 50).

${ }^{66}$ Hunt, op. cit. (note 30), 491.

${ }^{67}$ Jewsiewicki, op cit. (note 36), 169.

${ }^{68}$ Giles-Vernick et al., op cit. (note 50), 22.
} 



Figure 3. $A \& B$ : Annual incidence, in percentage, of treated cases for the conditions: (A) syphilis all stages, primo-secondary syphilis, urethral and cervical discharge ('blennorrhagie'); (B) chancroid (males), LGV venereal bubo condition (males).

Sources: Province du Congo-Kasai, op. cit. (note 3); Province de Léopoldville, op. cit. (note 3); RAACCB, op. cit. (note 4); RHPCB 1908-24, op. cit. (note 4); RHPCB 1925-58, op. cit. (note 4); Croix Rouge du Congo, op. cit. (note 6); AIMO, op. cit. (note 7); Duren, op. cit. (note 9); District Urbain de Léopoldville, op. cit. (note 9).

such before independence or that clients were approached in public. ${ }^{69}$ However, complementary evidence indicates that a minority of female sex workers had brief sexual encounters with clients, including with Europeans in the bush areas or 'neutral zones' separating the African and the European quarters, suggesting a high turnover. ${ }^{70}$ Second, colonial authorities already voiced suspicions regarding the existence of brothels in the 1920s, without however providing information on their location or definitive proof of their existence. ${ }^{71}$ And third, there are incidental reports of the police identifying prostitutes in Leopoldville by searching the city areas they were known to frequent, suggesting 'streetwalking'. ${ }^{72}$ All in all, it seems likely that high turnover sex workers would have been a tiny minority of the city's women and also a minority of those who engaged in some form of prostitution.

\section{Early STI incidence and health coverage}

Incidence rates of treated cases for syphilis, 'blennorrhagie' (in adults of both sexes), chancroid and LGV's venereal bubo (only in males), were based on data from the state sector, Industrial Hygiene and Croix Rouge combined. Chancroid patients who presented themselves for treatment were mostly and sometimes overwhelmingly male. ${ }^{73}$ The venereal bubo manifestation of LGV tends to occur in males. ${ }^{74}$ Assuming that, when gender of patients was not indicated, $90 \%$ of chancroid and venereal bubo cases were in males, reliable indications were obtained of the proportion of new syphilis cases detected in either the primary or the secondary stage. The evolution of these incidences is shown in Figure 3.

Incidence rates of treated cases peaked before the mid-1930s and then declined considerably. Following the introduction of antibiotics in 1947 they declined even more, to levels a hundred times lower than they had previously been. By the 1950s, low incidence rates suggested that STI therapeutics had been successful, reducing interest in further clinical research into related pathologies. ${ }^{75}$

\footnotetext{
${ }^{69}$ Pépin, op. cit. (note 13), 90.

${ }^{70}$ Alexandre Cabral, Histórias do Zaire (Lisboa: Livros Horizonte, 1947), 45-6, 98-9.

${ }^{71}$ Lauro, op. cit. (note 49), 166, 177.

${ }^{72}$ Ibid., 169. The same author suggests that police surveillance was inconsistent while officers appeared to act in deference to their superiors (page 170). Other descriptions referring to high turnover sex workers in colonial Africa, refer to Nairobi, with some prostitutes acting as 'streetwalkers' having brief contacts with clients, including Europeans who transported them secretively by car to the outskirts of the city; see White, op cit. (note 11).

${ }^{73}$ Ronald and Albritton, op. cit. (note 32), 391.

${ }^{74}$ Favre and Hellerström, op. cit. (note 35), 35.

${ }^{75}$ Goeman et al., op cit. (note 12), 794.
} 
Although the information for the years 1910-20 is scant, the available data suggest that this period may have been more acute in terms of STI epidemics and official perceptions of their severity. The first official measures to regulate prostitution and introduction of police-registers and medical screening in 1909 , appear to be a response to the authorities' heightened concerns regarding the spread of venereal diseases. ${ }^{76}$ Several isolated documents reporting systematic and compulsory monthly screening of public sector workers indicate very high levels of discharge ('blennorrhagie') for example in 1910-11, implying incidence rates of over 100\% per year (475 entries of 'blennorrhagie' detected in 1113 men in a period of 4 months). ${ }^{77}$ This incidence is far higher than any depicted in Figure 3 for the period 1919-58. The two types of data are not comparable, because the 1910-11 data refer to men screened very intensively and compulsively, while the data shown in Figure 3 refer to people presenting themselves spontaneously for treatment. It could however suggest a higher intensity of urethral discharge at that time, although we cannot be sure. A report of the Congo-Kasai province states that the venereal disease situation was much better in 1926 than in $1919-20 .^{78}$

Leopoldville's medical authorities were swift to adopt new drugs to treat venereal diseases immediately after they became internationally available. Thus, the arsenical drug arsphenamine (Salvarsan), effective against primary and secondary syphilis, was already in use there in 1912, 2 years after it came to the market. ${ }^{79}$ Another arsenical, Neoarsphenamine (NeoSalvarsan) was prescribed since $1920 .{ }^{80}$ NeoSalvarsan became very popular among Congolese afflicted by syphilis and yaws from the early 1920 s onwards. ${ }^{81}$ Similar trends have been observed in other colonies of Central Africa. ${ }^{82}$ However, cost constraints were used to justify irregular use among Africans before the mid-1920s, ${ }^{83}$ while reports for Boma (the capital at the time) indicated that supplies of arsenicals to treat syphilis only sufficed for Europeans. ${ }^{84}$ In 1922, for 492 syphilis cases in Africans treated in the DUL facilities, only 160 injections were administered, that is, an average of only 0.3 per patient. ${ }^{85}$ More complete and effective syphilis treatments required eight to twelve NeoSalvarsan and additional bismuthic injections per patient. ${ }^{86}$ Hence, very few patients were receiving adequate treatment at the time public health authorities were established. Even if doctors were administering only minimal treatments of one to three injections per patient (as they often did) most of the above cited 492 patients never received them. ${ }^{87}$ The 1918 report of the Hôpital des Noirs suggests that of the registered African sex workers from the city seeking treatment, only 139 received consultations, suggesting inconsistent health coverage for this high-risk group. ${ }^{88}$

Official negligence and asymmetric segregated services thus created the conditions for a high STI epidemicity among Africans in the 1920s. The extension of health care and the treatment of STIs to these

\footnotetext{
${ }^{76}$ Hunt, op. cit. (note 12), 115.

${ }^{77}$ Afrika-Archief (FO-BZBHO, Brussels), A11-4389(841), Service Médical, 'Résultats des examens médicaux mensuels pour les mois de Janvier et Février 1911', Leopoldville, Belgian Congo, 1911; Service Médical, 'Note explicative du relevé statistique des visites médicales mensuelles (Mars-Avril-Mai 1911)', Leopoldville, Belgian Congo, 1911. See also Sousa et al., op. cit. (note 14), Supplementary Text S1.

${ }^{78}$ Province du Congo-Kasai, op. cit. (note 3), 1926 report.

${ }^{79}$ R. Mouchet and A. Dubois, 'Le traitement du Pian et de la Syphilis par le Salvarsan dans la pratique indigène', Bulletin de la Societé de Pathologie Exotique, 6 (1913), 14-9.

${ }^{80}$ Goeman et al., op. cit. (note 12), 637.

${ }^{81}$ Walravens, op. cit. (note 21), 163.

${ }^{82}$ Louis-Paul Letonturier, 'Rapport sur le fonctionnement du service de santé au Cameroun pendant l'année 1923', Annales de Médecine et de Pharmacie Coloniales, 22 (1924), 396-408, 405.

${ }^{83}$ RAACCB, op. cit. (note 4); Walravens, op. cit. (note 21), 163-4.

${ }^{84} \mathrm{~V}$. Barthélemi, 'Étude sur la syphilis au Congo Belge' (unpublished manuscript, Library of the Institut voor Tropicale Geeneskunde, Antwerpen, Belgium, 1921), 8, URL: http://libra.itg.be:8000/webspirs/start.ws.

${ }^{85}$ Province du Congo-Kasai, op. cit. (note 3), 1922 report.

${ }^{86}$ Croix Rouge du Congo, op. cit. (note 6).

${ }^{87}$ In the early decades, doctors treated most syphilis patients with one or two, and sometimes three injections; for example, see Mouchet and Dubois, op. cit. (note 79).

${ }^{88}$ Afrika-Archief (FO-BZBHO, Brussels), RACCB 1046/Léopoldville, Service Médical de Léopoldville, 'Hôpital des Noirs et Lazaret, Rapport Annuel', Leopoldville, Belgian Congo, 1918.
} 
populations beyond the restricted category of 'prostitutes', was above all inspired by post WWI depopulation anxieties. ${ }^{89}$ The high male-biased sex ratio was seen by colonial authorities to favour prostitution and milder forms of 'sexual promiscuity', which needed to be combated. However, despite NeoSalvarsan's effectiveness against early syphilis, and Africans' enthusiasm for this new 'magic bullet', five factors limited its impact. First, financial resources were scarce, as health services were still in their initial phase and medical supplies were limited. Second, official priorities at that stage clearly favoured settler populations, thereby excluding most Africans from treatment. Third, even when Africans managed to access treatment, they were not necessarily cured, as they failed to complete long series of injections of arsenical and bismuthic salts. Following a few initial NeoSalvarsan injections, enough to treat external symptoms, patients failed to return without however curing the disease, thereby potentially increasing contagion. Fourth, at the time no effective medications existed against the other STIs. ${ }^{90}$ And finally, whereas male workers were regularly treated, and the 'boys' (male African servants employed by Europeans) had access to treatment at the behest of their employers, women's access to treatment remained extremely limited. Consultations and interned patients in Leopoldville for 1926-8 broken down by gender reveal a male/female ratio of ten to one, well above the population ratio. ${ }^{91}$ These factors determined that STI infectious stages would tend to run their natural course and duration owing to a lack of effective treatment, which in turn boosted successive STI epidemics (Figure 3).

\section{Redrawing urban boundaries and STI control}

From 1929 onwards, major changes in the combat against STIs took place. First and foremost, the Croix Rouge du Congo (a filial of Croix Rouge de Belgique) opened a clinic offering free treatment of STIs in Leo-East (Kinshasa). It maintained good standards of treatment compared to rural dispensaries, complementing series of arsenic injections with bismuth injections. Its reports show that long-term treatments of syphilis, involving successive injections per patient, were being performed, potentially resulting in full cure. In addition, the Croix Rouge personnel operated mobile teams visiting people at home, collecting blood for BordetWassermann tests and screening people for symptomatic STIs. This was a massive effort: by 1932, the report claims, somewhat overconfidently, that almost all the women of Leo-East had been examined..$^{92}$ In 1934, a similar clinic was inaugurated in the lesser populated Leo-West, following similar procedures. Unlike state run hospitals, the Croix Rouge also encouraged femmes libres to register for monthly examinations.

In 1931, the Belgian colonial government introduced the Décret sur les Centres Extra-Coutumiers (CEC) to reorganise the periphery of the Congo's major urban centres and its African quarters. ${ }^{93}$ The measure grew out of the concern that African urban migrants did not fall under the customary regime upheld by administrators and appointed indigenous chiefs in rural areas. Authorities considered that the dynamics of 'detribalisation' would aggravate social and moral dissolution, thus emphasising women's social and reproductive role within the ideal of the nuclear family. ${ }^{94}$ Married African women were legally prohibited from engaging in income generation, being the exclusive province of the husband; wives required formal permission from the latter to exercise remunerated activities. As single women did not fit this ideal-typed model, CECs acted as convenient tools for social control and persuasion, in conjunction with tighter local policing and an active judiciary. This in turn probably induced femmes libres to refine covert strategies in the informal sector. ${ }^{95}$

\footnotetext{
${ }^{89}$ Hunt, op. cit. (note 1), 116.

${ }^{90}$ Goeman et al., op. cit. (note 12), 637; Richard Steen, 'Eradicating chancroid', Bulletin of the World Health Organization, 79, 9 (2001), 818-26.

${ }^{91}$ Province du Congo-Kasai, op. cit. (note 3 ).

${ }^{92}$ Croix Rouge du Congo, op. cit. (note 6), 1932 report.

${ }^{93}$ L. de Clerck, 'L'administration coloniale belge sur le terrain au Congo (1908-1960) et au Ruanda-Urundi (1925-1962)', L'Annuaire d'Histoire Administrative Européenne, 18 (2006), 187-210.

${ }^{94}$ Hunt, op. cit. (note 30), 451.

${ }^{95}$ Gondola, op cit. (note 48), 5/6.
} 
As a result, several such CECs drew clearly demarcated areas for Africans (or 'indigènes') which also functioned as cordon sanitaires. Previously, from 1919 onwards, Polices Municipales were introduced in the colony's main cities (Boma, Matadi, Leopoldville and Elisabethville), and in 1926-7 the first police forces were set up under civilian control. As a result, systems of administrative urban demarcation and surveillance were put in place, which would continue to operate until the end of the colonial period. ${ }^{96}$ Urban regimentation in effect shifted contact to contingent areas rather than inhibiting it. For example, the city's main public market refashioned in 1925 had rapidly developed into a site of social interaction where different European and African nationalities and ethnicities met, thus bridging barriers. Complaints from the European community prompted the city's Urban Committee to move the market to the 'neutral zone' in 1943 in an effort to relocate 'inter-racial' encounters to peripheral areas beyond the European quarter. ${ }^{97}$ However, effectively policing these boundaries proved impossible: by the mid-1940s, the city's police force was seen to be weak on the ground, unable to deal with 'interracial incidents' or with juvenile (male) delinquency. ${ }^{98}$ UC's members including African notables at district level, voiced their concern about police violence and brutality calling for more tactful policing methods that took into account local problems. Despite the post- 1945 shift towards welfarist policies, they failed to result in reforms of the Leopoldville's Force Publique or the application of less coercive methods, on account of the fear of rising anti-colonial sentiment and social tensions. ${ }^{99}$

In terms of public health, designated African quarters were divided into 'zones' and 'secteurs' for purposes of sanitary inspection as well as disease and vector control. These 'Cités Indigènes', separated by so called 'neutral zones' from European wards were to become a salient feature of the urban landscape. ${ }^{100}$ The new 'native' quarters attracted rural Africans from different areas and a variety of ethnic groups seeking improved living conditions, housing, employment and services. As a result, the population of Cités such as Kinshasa doubled in size between 1926 and 1940, and again between 1940 and $1945 .{ }^{101}$ The growing populations in these urban peripheries came to the attention of organisations philantropiques operating in the realm of public health, such as the Croix Rouge du Congo, which stepped in where colonial authorities failed to act.

In the period 1931-5, the Croix Rouge was already treating as many syphilis cases in the city as all the government hospitals and clinics combined. Later, it increased its efforts. It was also treating an increasing number of cases of urethral or cervical discharge ('blennorrhagie') using trypaflavine and other methods of limited efficacy. The period 1929-35 also saw an increase in anti-venereal activity by the private companies (Hygiène Industrielle). Some big companies, such as the fluvial transportation company Unatra, the palm oil processer Huileries du Congo Belge (HCB) and the textile factory Texaf already ran clinics in Leopoldville to treat their workers in the 1920s, their activity increasing after 1929.

There was a substantial increase in treated cases of syphilis and discharge in the period 1929-35 compared to previous years (Figure 3), although the data are not suitable for a statistical test of this trend. This increase probably reflects more intense anti-venereal campaigns rather than the epidemic increase of the diseases. Indeed, STI epidemics were almost certainly more intense in the 1920s, which led Dr. G. Trolli, the head of the colony health services to write that, in Leopoldville, in 1930, syphilis was already in retreat'. ${ }^{102}$ The increase of treated cases in the period 1929-35 probably reflects increased awareness of available treatments by Africans and their greater knowledge of symptoms, significance. For example, in

\footnotetext{
${ }^{96}$ Amandine Lauro, 'Maintenir l'ordre dans la colonie-modèle. Notes sur les désordres urbains et la police des frontières raciales au Congo Belge (1918-1945)', Crime, Histoire \& Sociétés, 15, 2 (2011), 97-121: op. cit. 109-11.

${ }^{97}$ Beeckmans, op cit. (note 7$), 3$.

${ }^{98}$ Ibid.

${ }^{99}$ Lauro, op cit. (note 44), 67-75.

${ }^{100}$ Kibayu, op. cit. (note 27), 34-7.

${ }^{101}$ A. Mandjale and O. Iba Ngambong, 'From the colonial era to the present: demography of Zaire', in: P.G. Janssens, M. Kivits and J. Vuylsteke (eds), Health in Central Africa Since 1885: Past, Present and Future (Brussels: King Baudoin Foundation, 1997), 17-36: 21.

${ }^{102}$ G. Trolli, 'Rapport sur la Situation Sanitaire Générale du Congo Belge en 1930', Annales de la Societé Belge de Médicine Tropicale, 12 (1932), 587-726: 671.
} 
1933 it was observed that Africans were grasping the relevance of the syphilitic primary chancre and were increasingly seeking treatment for it, reversing their past insouciance regarding that syphilitic stage. ${ }^{103}$

The decline in syphilis cases after 1935 was pronounced: between 1929-35 and 1936-41, the mean incidence of all treated syphilis cases and of primo-secondary syphilis separately dropped from $6.5 \%$ to $4.2 \%$ and from $2.9 \%$ to $1.2 \%$, respectively (Figure 3). Most likely, this corresponds to a real epidemic decline as mass screening and combined arsenic and bismuthic treatments were reducing the pool of infectious people. Syphilis at any stage declined less pronouncedly than primo-secondary as the share of tertiary cases was increasing. Patients without any symptoms were also being treated as a result of Bordet-Wassermann reactive tests despite having a low specificity for syphilis. The decline of the proportion of primo-secondary cases in all detected syphilis cases, as an epidemic matures, is a wellknown phenomenon in syphilis epidemiology. ${ }^{104}$

\section{Therapeutic innovation and social diseases}

The mass exodus of rural populations towards the main urban centres which started during the Second World War, triggered by military and labour recruitment campaigns, was to change their demographic composition. In cities such as the capital Leopoldville which saw its population double during the war, alarmist reports about the 'indisciplined behaviour' of Africans began to circulate with greater intensity. At the same time, officials were concerned about the changing composition of the European population with the arrival of 'less desirable' elements, the 'nouveaux arrivès' pursuing 'reckless lifestyles' and frequenting the club circuits of the Cités Indigènes. ${ }^{105}$ Urban planners drew up schemes for a 'nouvelle Cité [indigène]' which was erected from 1945 onwards in an area south of the old Cité in the capital, adjacent to the Ndolo airport. It was run by a coordinating body, the Office des Cités Indigènes (OCI) from 1949 onwards. Divided into quartiers, the new Cité was devised as a segregated African suburban settlement with a range of services, including education, health and transport services, and included in the Ten-Year Plan (1949-59). These initiatives were accompanied by a shift of focus in public health policies towards the combat against social diseases, such as leprosy, tuberculosis and STIs. ${ }^{106}$

Sulfonamides, first marketed in 1937, constituted a major breakthrough in the combat against and control of gonorrhoea, chlamydia and chancroid infections. ${ }^{107}$ They started to be prescribed in Leopoldville in that same year. ${ }^{108}$ Sulfanilamide and sulfamidopyridine were the preferred treatments particularly against 'blennorrhagie', although the old trypaflavine regime was not abandoned. As Figure 3 shows, blennorrhagie, chancroid and LGV cases declined significantly only after 1937-9, most likely reflecting the fact that the new treatments accelerated outcomes, thus reducing infectious periods.

Penicillin use in the city is first mentioned in Croix Rouge reports in 1947, earlier than in French colonies. ${ }^{109}$ By 1950, penicillin administration was almost equal to that of arsenics in the number of injections given and by 1954 it had largely surpassed them. ${ }^{110}$ The mass administration of penicillin and other antibiotics provoked a steeper decline in chancroid and LGV after 1950, as is evident from Figure 3. This trend led to infectious, ulcerative stages of STIs becoming rare. For example, the numbers

\footnotetext{
${ }^{103} \mathrm{~F}$. Van den Branden and A. Dubois, 'La syphilis congolaise et son influence dans la pathologie tropicale', Bruxelles Médical, 13 (1933), 136-45: 137

${ }^{104}$ Geoff P. Garnett, Sevgi O. Aral, Deborah V. Hoyle, et al., 'The Natural History of Syphilis: Implications for the Transmission Dynamics and Control of Infection', Sexually Transmitted Diseases, 24 (1997), 185-200, URL: https://journal s.lww.com/stdjournal/Fulltext/1997/04000/The_Natural_History_of_Syphilis_Implications_for.2.aspx.

${ }^{105}$ Lauro, op. cit. (note 96), 115-16.

${ }^{106}$ J. André, J. Burke, J. Vuylsteke et al., 'Evolution of health services', in P.G. Janssens, M. Kivits and M. Vuylsteke (eds), Health in Central Africa Since 1885: Past, Present and Future (Brussels: King Baudoin Foundation, 1997), 89-158: 137.

${ }^{107}$ Goeman et al., op. cit. (note 12); Steen, op. cit. (note 90$)$.

${ }^{108}$ RHPCB 1925-58, op. cit. (note 4), 1937 report.

${ }^{109}$ Croix Rouge du Congo, op. cit. (note 6), 1947 report; for French colonies, see reports in ANOM and IMTSSA archives (see Appendix).

${ }^{110}$ Croix Rouge du Congo, op. cit. (note 6), 1954 report.
} 
of primo-secondary syphilis cases in 1956, 1957 and 1958 were fourteen, eleven and twenty-five, respectively, in a city that had surpassed 300000 inhabitants. Chancroid cases were less than forty per year and LGV less than twelve. ${ }^{111}$ Early syphilis, chancroid and LGV incidence rates declined to levels about one hundred times lower than they had been decades before. The small rebounds seen after 1956 reflect the resumption of mass screening campaigns. ${ }^{12}$ By 1951, the two Croix Rouge clinics performed 31170 examinations of 3500 femmes libres, implying that each registered femme libre was being examined about nine times a year. ${ }^{113}$ In the years 1956, 1957 and 1958 the number of 'prostitutes regularly observed' by the clinics was 2966,3761 and 4384, respectively. ${ }^{114}$ By that time, Bruaux and colleagues estimated that 5000-6000 women 'lived exclusively on prostitution'. ${ }^{115}$ One decade earlier (when the city population was about one third), Capelle estimated that 5000 femmes libres paid the special tax, adding that 'almost all' were 'prostitutes', a likely exaggeration. ${ }^{116}$.

The decline of urethral and cervical discharge was not as significant as the decline of the above conditions, presumably because its main agents, Neisseria gonorrhoea and Chlamydia trachomatis, cause many longlasting asymptomatic infections in women, who by avoiding exposure of their 'shameful afflictions'117 escaped treatment thus maintaining significant human reservoirs. ${ }^{118}$ The numbers for total syphilis treated declined only by a factor of about ten, because even in the late 1950s, Leopoldville's medical staff were still massively treating latent cases with mere serological signs of treponematosis (syphilis or yaws).

In 1955, the Croix Rouge clinics were incorporated in the government health system renamed Centre de Prophylaxie Anti-Venériénne. Despite the lack of resources and shortcomings during the early decades, clinical data appear to suggest STI control in Leopoldville was successful. The highest epidemicity of STIs was certainly previous to 1935 (Figure 3) and probably occurred before 1925. As argued above, the epidemic of genital ulcer diseases (syphilis, chancroid and LGV) in Leopoldville may have played a major role in the emergence and initial spread of HIV-1. ${ }^{119}$ Discharge and inflammatory STIs also peaked during the early twentieth century, and this phenomenon might have played a role in increasing HIV transmission. Phylogenetic analysis reveals that this virus epidemic started in Leopoldville around the time of maximal genital ulcer disease incidence. ${ }^{120}$ In any case, data for the period 191628 show highly epidemic STI rates at a time when adequate treatment for STIs other than syphilis was lacking, whilst anti-syphilis arsenical drug use in Africans remained restricted owing to racially imbued policies, leaving these diseases to ravage the city's indigenous population almost entirely unopposed.

\section{Conclusions}

Longitudinal data series collated for treated STI cases in Leopoldville, for most years during the period 1919-58, and available demographic data, allow for tracing the incidence of treated cases of STIs during

\footnotetext{
${ }^{111}$ Province de Léopoldville, op. cit. (note 3); Bruaux et al., op. cit. (note 13).

${ }^{112}$ Province de Léopoldville, op. cit. (note 3); RHPCB 1925-58, op. cit. (note 4).

${ }^{113}$ Croix Rouge du Congo, op. cit. (note 6), 1951 report.

${ }^{114}$ Afrika-Archief (FO-BZBHO, Brussels), A39-RA- RA/MED-18, 'Ville de Léopoldville, Service de l'Hygiène Publique, Rapport Annuel 1958', Leopoldville, Belgian Congo: Service de l'Hygiène Publique, 1958. Medical authorities often used the terms 'prostitute' and 'femme libre' interchangeably.

${ }^{115}$ Bruaux et al., op. cit. (note 30$)$.

${ }^{116}$ Emmanuel Capelle, La Cité Indigène de Léopoldville (Leopoldville, Belgian Congo: Centre d'Études Sociales Africaines, 1947), 59.

${ }^{117}$ Hunt, op cit. (note 12), 123.

${ }^{118}$ Eline L. Korenromp, Mondastri K. Sudaryo, Sake J. de Vlas, et al., 'What Proportion of Episodes of Gonorrhoea and Chlamydia Becomes Symptomatic?', International Journal for STD and AIDS, 13 (2002), 91-101: 96-7.

${ }^{119}$ Sousa et al. 2010, op. cit. (note 14); João Dinis Sousa, Viktor Müller and Anne-Mieke Vandamme, 'The Epidemic Emergence of HIV: What Novel Enabling Factors Were Involved?', Future Virology, 12, 11 (2017), 685-707, URL: https:// doi.org/10.2217/fvl-2017-0042.

${ }^{120}$ Nuno R. Faria, Andrew Rambaut, Marc A. Suchard, et al., 'The Early Spread and Epidemic Ignition of HIV-1 in Human Populations', Science, 346, 6205 (2014), 56-61, URL: http://science.sciencemag.org/content/346/6205/56.
} 
this period. Despite limitations associated with diagnostic errors resulting from overlapping symptoms, the lack of specificity of serological tests and cell cultures, and non-specific disease characterisation, we believe our data provide a valuable tool for tracking general temporal trends of the incidence of treated cases of syphilis, chancroid, LGV and the discharge syndrome. Our data show that screening and treatment campaigns had a major impact on STI reduction. Whereas previous to 1929 most STI cases were not effectively treated, the first large-scale campaign which coincided with the establishment of the Croix Rouge clinics in Leopoldville and its therapeutic regime, prompted an apparent decline in new syphilis cases after 1934 (Figure 3). Subsequently, the introduction of sulfonamides in 1937, coinciding with their arrival on the world market, marks a decline thereafter in chancroid, LGV and dischargeinduceing STI cases (Figure 3), probably reflecting this new and more effective treatment. Finally, the use of penicillin and other antibiotics after 1947 produced a further decline in STI cases. All in all, the incidence of ulcerative stages of STIs decreased by a factor of one hundred between the 1920s and the late 1950s, illustrating the positive impact of improvements in coverage, diagnostic tests, treatment and raised awareness among the African population.

Increased coverage, and improved diagnostics and treatment facilities targeting Africans emerged in a context of enhanced population management and control in a push towards the modernisation and 'sanitisation' of the capital city. These policies coincided with the 1929 economic depression and a worsening of socio-economic conditions for Africans, further aggravated by government policies. Enhanced STI related interventions should therefore be perceived not only as means of attracting African patients, but also as a corollary of the redrawing and heightened surveillance of urban boundaries fed by demographic, social, economic and securitarian concerns. After 1929, the policing of these boundaries and the medicalisation of STIs by a segregated health system set out to neutralise the perceived threat of African disease reservoirs whilst restricting urban 'inter-racial' sexual relations. By channelling public health messaging via evolué groups and African dignitaries, authorities reinforced socially stratified STI awareness campaigns.

Although declining official STI rates appear to confirm the apparent success of these inter-connected strategies, especially after 1945, they hide underlying social, economic and cultural changes in a 'model colony'. Economic hardship experienced by African households and rapidly growing informal settlements in the 1930s triggered a possible shift in coping strategies and health seeking behaviour on the part of recently urbanised African populations. However, colonial health reports provide limited evidence on their attitudes towards biomedical treatments, facilities and awareness campaigns or on their pluralist medical strategies. ${ }^{121}$ Sources suggest that STI clinics were established for a male clientele, thus potentially alienating most women. ${ }^{122}$ Socio-historical evidence suggests that far from conforming to Western domesticity, African women, including femmes libres, whose numbers grew from the 1920s onwards, engaged in informal income generation and social liaisons which alarmed and confounded authorities, thereupon stigmatising and criminalising them as sex workers and moral offenders. The great influx of young African men into the Citès Indigènes, and the resulting significant gender imbalance also informed a tightening of health surveillance and coercive policing.

The failure of the policy of social control and containment by an authoritarian colonial state from a population and health management perspective, is evident from the data gaps regarding African women. Despite - or precisely because - being officially stigmatised as sex workers, who were rounded up and expelled from the city from the 1930s, African women devised coping strategies to operate under public health and police radars, in a 'grey zone' beyond the reach of sanitary campaigns. ${ }^{123}$ STI data are therefore subject to a number of caveats. Besides reflecting improved health coverage, diagnostics and treatment outcomes, declining STI rates especially after 1945 could be associated with possible shifts in (pluralist) health seeking strategies and behaviour. Given that only limited evidence is provided in colonial health reports on how social diseases, STIs and their medicalisation were viewed and acted upon by urbanised Africans, additional qualitative research is needed.

\footnotetext{
${ }^{121}$ Hunt, op. cit. (note 12$)$.

${ }^{122}$ Comhaire-Sylvain, op cit. (note 60), 30; Pépin op cit. (note 13), 160.

${ }^{123}$ Hunt, op. cit. (note 12), 122/123.
} 


\section{Appendix}

To obtain data about the Belgian Congo, we consulted the Afrika-Archief, Federale Overheidsdients Buitenlandse Zaken, Buitenlandse Handel en Ontwikkelingssamenwerking (FO-BZBHO) (Ministry of Foreign Affairs), Brussels.

To obtain data about French colonies, Archives Nationales d'Outre-Mer (ANOM), Aix-en-Provence, France and the Archives of the Institut de Médecine Tropicale du Service de Santé des Armées (IMTSSA), Marseille, France were consulted.

The data displayed in Figure 1 were obtained, for the Belgian Congo, from colonial health reports, already mentioned in the main text. ${ }^{124}$ Part of the data pertaining to Cameroon, French Ivory Coast and French Guinea (period 1927-39) were retrieved from a set of long articles appearing in the journals Annales de Médecine et de Pharmacie Coloniales and Médecine Tropicale, exhaustively quantifying the incidence of treated cases for the main diseases in all French colonies. ${ }^{125}$

For Cameroon, we obtained additional data from the reports from the French administration to the League of Nations and colonial health reports. ${ }^{126}$ For the French Ivory Coast, we obtained additional data from colonial health reports and additional sources. ${ }^{127}$ For French Guinea, we obtained additional data from colonial health reports. ${ }^{128}$

\footnotetext{
${ }^{124}$ RAACCB, op. cit. (note 4); RHPCB 1908-24, op. cit. (note 4); RHPCB 1925-58, op. cit. (note 4).

${ }^{125}$ Maurice Rousseau, 'Les maladies transmissibles observées dans les colonies françaises et territoires sous mandat pendant l'année 1927', Annales de Médecine et de Pharmacie Coloniales [hereafter 'AMPC'], 27 (1929), 145-246; P. Hermant, 'Les maladies transmissibles observées dans les colonies françaises et territoires sous mandat pendant l'année 1928', AMPC, 29 (1931), 5-138; Georges Ledentu, 'Les maladies transmissibles observées dans les colonies françaises et territoires sous mandat pendant l'année 1929', AMPC, 29 (1931), 661-849; R. Lefèvre, 'Les maladies transmissibles observées dans les colonies françaises et territoires sous mandat pendant l'année 1930', AMPC, 30 (1932), 296-405 and 546-69; Edouard Marque, 'Les maladies transmissibles observées dans les colonies françaises et territoires sous mandat pendant l'année 1931', AMPC, 31 (1933), 123-323; Jean Grosfillez, 'Les principales maladies observées dans les colonies françaises et territoires sous mandat en 1932', AMPC, 32 (1934), 153-268; Georges Ledentu, 'Les maladies transmissibles observées dans les colonies françaises et territoires sous mandat pendant l'année 1933', AMPC, 33 (1935), 552-816; Georges Ledentu, 'Les maladies transmissibles observées dans les colonies françaises et territoires sous mandat pendant l'année 1934', AMPC, 34 (1936), 474-749; Georges Ledentu and M. Peltier, 'Les maladies transmissibles observées dans les colonies françaises et territoires sous mandat pendant l'année 1935', AMPC, 35 (1937), 748-928 and 1207-335; E. Vogel and Jules Le Rouzic, 'Les maladies transmissibles observées dans les colonies françaises et territoires sous mandat pendant l'année 1936', AMPC, 36 (1938), 352-520 and 633-725; E. Vogel and M. Riou, 'Les maladies épidémiques, endémiques, et sociales dans les colonies françaises pendant l'année 1937', AMPC, 37 (1939), 257-551; Jean Grosfillez and R. Lefèvre 'Les maladies transmissibles observées dans les colonies françaises et territoires sous mandat pendant l'année 1938', AMPC, 38 (1940), 183-359; R. Le Gall, 'Rapport du Ministère des Colonies sur les maladies pestilentielles et les maladies endémo-épidémiques dans l'Empire Colonial Français au cours de l'année 1939', Médecine Tropicale, 1 (1941), 575-954.

${ }^{126}$ Cameroon, Rapport annuel adressé par le Gouvernement Français au Conseil de la Société des Nations sur l'administration sous mandat du territoire du Cameroun pour l'année [1921 to 1939] (Paris: Imprimerie Générale Lahure, 1921-39); IMTSSA, Box 112, Cameroon, 'Les Services de la Santé Publique du Cameroun en [1955-8]', Yaoundé, Cameroon: Services de Santé, 1955-8.

${ }^{127}$ Gustave Bouffard, 'L'Assistance Médicale en Côte d'Ivoire pendant l'Année 1925', Annales de Médecine et de Pharmacie Coloniales, 25 (1927), 309-48; Danielle Domergue-Cloarec, La Santé en Côte d'Ivoire, 1905-1958 (Toulouse: Association des Publications Université Toulouse-Le Mirail, 1986); ANOM, 14 Mi 2G31-2G37 (mifi), 'Rapport médical annuel, Colonie de la Côte d'Ivoire [1931-7]', Abidjan, Côte d'Ivoire: Service de Santé, 1931-37; IMTSSA, Boxes 45, 46, 47, 50, 'Colonie de la Côte d'Ivoire, Service de Santé, Rapport annuel [1943-9]', Abidjan, Côte d’Ivoire: Service de Santé, 1943-9; IMTSSA, Boxes 46, 47, 48, 49, 'Colonie de la Côte d'Ivoire, Direction Locale de Santé Publique, Rapport annuel [1950-8]', Abidjan, Côte d'Ivoire: Direction Locale de Santé Publique, 1950-8.

${ }^{128}$ ANOM, 14 Mi, 2G31-2G37 (mifi), 'Rapport annuel médical, Colonie de la Guinée Française [1931-7]', Conakry, Guinée Française: Service de Santé, 1931-7; IMTSSA, Box 44, 'Colonie de la Guinée Française, Rapport médical annuel [1940-9]', Conakry, Guinée Française: Service de Santé, 1940-9; IMTSSA, Box 44, 'Colonie de la Guinée Française, Direction Locale de Santé Publique, Rapport annuel [1950-8]’, Conakry, Guinée Française: Direction Locale de Santé Publique, 1950-8.
}

Cite this article: Sousa JD, Havik PJ, Vandamme A-M (2021). Sexually transmitted infections, their treatment and urban change in colonial Leopoldville, 1910-1960. Medical History 65: 178-196, https://doi.org/10.1017/mdh.2021.11 